\title{
SiBakul Jogja Free Shipping: Empowerment to Turn on the Economy of Yogyakarta's MSMEs in Pandemic Era
}

\author{
Nur Faidati \\ Universitas Aisyiyah Yogyakarta (email: nurfaidati18@gmail.com) \\ Muhammad Khozin \\ Gerry Katon Mahendra
}

\begin{abstract}
This study focuses on the efforts made by the government to make MSMEs survive and their products accessible to consumers in this pandemic era. The real problem for MSMEs in this pandemic era is rebuilding a sluggish economy due to a number of policies that require people to be at home to reduce the spread of the Covid-19. The research method used in this research is descriptive exploratory qualitative research method. This study uses a desk study and interview technique. Desk studies are carried out through secondary data tracking. Interviews were conducted with regional apparatus organizations (OPD) which handle MSMEs and MSMEs' actor. From the research conducted, it is known that SiBakul Jogja Free Shipping is enough to be the answer to reviving the economy for MSMEs who are still struggling through the Covid-19 pandemic to get their market back, without visiting consumers or making conventional transactions.
\end{abstract}

\section{Keywords: \\ MSMEs; Covid-19; Empowerment}

\section{Introduction}

This study focuses on the Yogyakarta's government innovation in striving for MSMEs' survival and their products remain accessible to consumers in the era of the Covid-19 pandemic. MSMEs cannot be separated from the bad effects of the Covid-19 pandemic (Shafi, Liu, Ren, 2020; Hadi, 2020; Adian, Doumbia, Gregory, Ragoussis, Reddy, Timmis, 2020; Papadopoulos, Baltas, Balta, 2020). Unlike the 1998 crisis, where the bad impact was more on big businesses, the Covid-19 pandemic also targeted MSMEs (Amri, 2020). Many MSMEs have experienced a decrease in income and have to stop their business. Based on a survey conducted by the international labor organization (ILO) in Indonesia during the period April, $24-26,2020$, it was found that almost 70 percent of MSMEs stopped production. As many as 63 percent of MSMEs ask their employees to take paid or unpaid leave. As many as 90 percent experienced cash flow problems (Katadata, 2020). 
The problems faced by MSMEs were caused by an economic slowdown that emerged as a result of the pandemic (Dev and Sengupta, 2020). The economy slowdown due to the effects of social and physical distancing. The existence of social and physical distancing then causes delays in the delivery of products and services from producers to consumers (Suprihatin, 2020). Then, it also causes people to be unable to attend wedding receptions, conferences, lectures, business meetings, tourist visits, meetings, and so on. At that point in time, it lowered people's interest in visiting restaurants, malls and other crowd centers. As a result, the income of MSMEs is reduced.

Reporting from the Bappenas website, in Indonesia MSMEs have a major contribution, namely: expansion of employment opportunities and absorption of labor, formation of gross domestic product (GDP) and safety net providers, especially for low-income people to carry out productive economic activities (Bappenas, 2014). Cited from Tambunan's MSMEs in Indonesia (2020), also have an important role in economic development and growth.

In the second quarter of 2020, Yogyakarta's economy came under increasing pressure. After growing $-0.17 \%$ (yoy) in the first quarter of 2020, the performance of the Yogyakarta's economy in the second quarter of 2020 decreased by $-6.74 \%$ (yoy), lower than the national economy which contracted to grow $-5.32 \%$ (yoy). The quite deep contraction of the Yogyakarta's economy originated mainly from the decline in the performance of the tourism industry and several supporting sectors, namely MSMEs.

Figure 1.

Performance of Yogyakarta's MSMEs

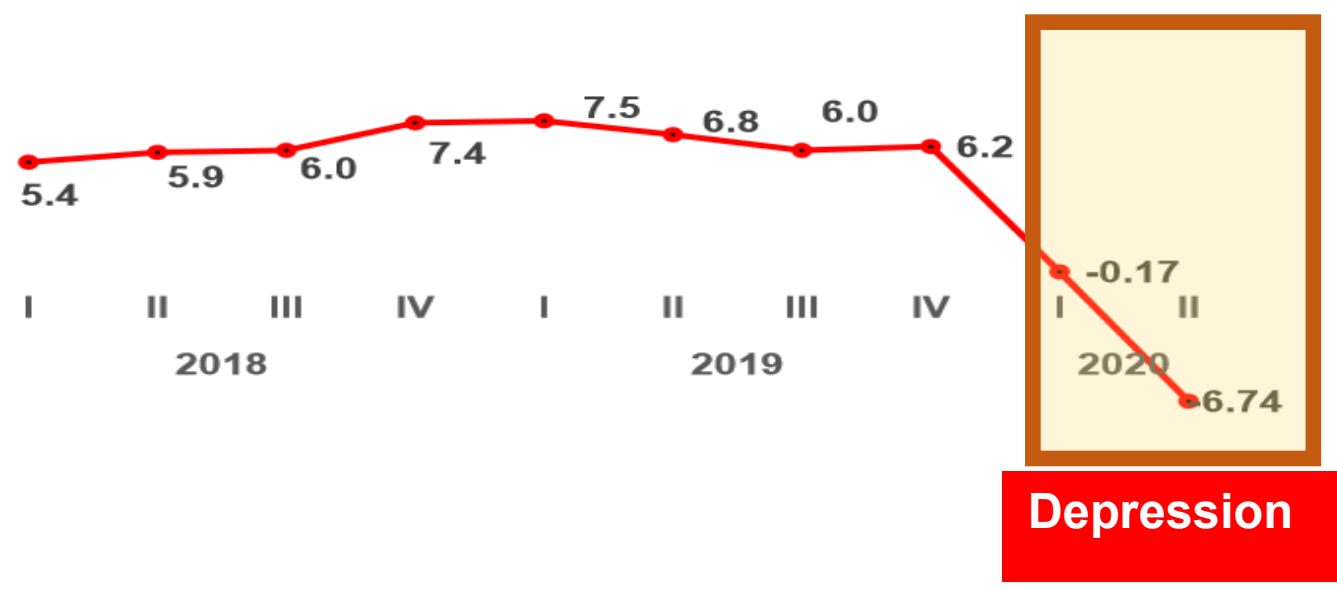

Source: Yogyakarta Office of Cooperatives and MSMEs, 2020

In Yogyakarta, MSMEs are still the main pillar of the provincial economy. Data for 2019 shows that the contribution of MSMEs to the provincial economy reaches 98.4 percent. 
Meanwhile, MSMEs are able to absorb 79 percent of total employment (Yogyakarta Office of Cooperatives and MSMEs, 2019). This data was supported by business actors totaling 248,499 business units. However, the absence of activities in the tourist area until the implementation of online learning has made the marketing of MSMEs actors in this city are jammed. More than 59 percent of MSMEs actors admit that they have difficulty in marketing because of the absence of tourism(https://www.viva.co.id/berita/bisnis/1287269-59-persen-umkm-di-diyterdampak-pandemi-virus-corona). The hotel is also closed. Education furthermore carried out online, so that MSMEs do not have buyers. Not only from the culinary sector, Yogyakarta also has around 78,000 small and medium industries that support the trade sector. This sector forms the informal workers or gig workers in Yogyakarta and forms the backbone of the Yogyakarta's economy with a fairly large contribution. Moreover, the COVID-19 pandemic has also made MSMEs' actors unable to move. Apart from marketing difficulties, the LargeScale Social Restriction (PSBB) policy in a number of regions also made it difficult for MSMEs in Yogyakarta to obtain raw materials. Regions that implement PSBB automatically cannot send the raw materials needed by MSMEs in Yogyakarta.

The number of policy developments that have responded to this problem has led to a lot of research on this topic. Among these studies is research on steps that can be used by policy makers to help entrepreneurs face the challenges of the COVID-19 pandemic (Kuckertz, A., Brändle, L., Gaudig, A., Hinderer, S., Reyes, C. A. M., Prochotta, A., ... \& Berger, E. S. 2020). Another study is about setting corporate financing policies during the decline in turnover in this pandemic era (Didier, T., Huneeus, F., Larrain, M., \& Schmukler, S. L., 2020). Another research is conducted by Pakpahan (2020) which seeks to analyze the impact of the COVID19 pandemic on the existence of MSMEs in Indonesia and provide emergency solutions for MSMEs in surviving in a pandemic and post pandemic era.

To fill the gap, this article will focus on policy innovation in order to make MSMEs survive and to make their products accessible to consumers in this pandemic era. While current literature has partially investigated strategic steps that must be taken by the government and other stakeholders that support MSMEs to survive in the pandemic era, policy innovations that specifically intervene in MSMEs are rarely discussed. Perhaps this is because innovation is more focused on governance or MSME institutions and not on policy innovation from the government. 
Policy innovation is a policy which is new to the states adopting it, no matter how old the program may be or how many other states may have adopted it (Tyran \& Sausgruber, 2005). Innovation is an integral part of the demands of public organizations both in the central and regional governments. Public policy innovation responds to various changes and dynamics of community demands. At the government level, both local and central government, the ability to innovate, especially policy innovation, is part of the ability to utilize potential resources both locally and nationally, supported by bureaucratic creativity at various levels. There are several objectives for policy innovation, including to increase competitiveness and provide impact and benefits for the public interest. One of the important prerequisites for encouraging the growth of policy innovation is the creativity of the bureaucracy in creating the power for change and new ideas.

\section{Methods}

The research method used in this research is descriptive exploratory qualitative research method. This research method is a research that produces descriptive data about spoken and written words, and observable behavior of the people studied (Taylor and Bogdan, 1984). Meanwhile, descriptive qualitative research is a type of research that aims to explain something through a study that aims to describe it, not looking at relationships or comparing (Ulum and Juanda, 2016). Qualitative descriptive research here is to explore how The Yogyakarta Office of Cooperatives and MSMEs (Dinas Koperasi dan UMKM) formulate this innovation policy, so that it can respond to the problems faced by MSME's actors in Yogyakarta.This research has been carried out during September - November, 2020 in The Yogyakarta Office of Cooperatives and MSMEs and several MSMEs' actors.

Moreover, in this research, the researcher utilizes two data collection methods:

\section{- Desk Study}

This method is used in order to examine archives relating to problems being researched; for instance, letters, memorandums, meeting notes, administrative documents, announcements, scrapbooked materials, news, or articles sourced from mass media, and so on. Desk study is also employed to examine literatures from the past such as books, reports, academic works, and other similar documents that relate to the research problems. 


\section{- Interview}

This method is used to gain information from those involved in the process of formulating documents, such as The Yogyakarta Office of Cooperatives and MSMEs.

\section{Data Analysis Method}

Data analysis method is an integral part of data collection. Moreover, this research is based on qualitative data. Data analysis is the process of collecting and systematically formulating the data obtained from interviews, fieldwork notes, and other documentation by organizing data into categories, translate them into units, synthesize, grouping them into patterns, prioritizing important ones and further examining them, and then formulating a clear conclusion that is easily understandable by the researcher themselves and others. (Sugiyono, 2012)

The process of analyzing and understanding data begins by examining all data available from various sources, such as interviews, observation conducted through fieldwork, documentation made in the span of data collection stage, pictures, photos, and et cetera. Therefore, there would be plenty of data; however after reading, understanding and examining, the next step is to reduce those data by abstraction. Abstraction is a way to outline the synthesis of those data, including the processes and statements that needed to be preserved within. The next step is to formulate them within units. These units are categorized in the steps that follow. These categories are formulated by coding. The last step of the data analysis process is by checking the validity of the data and after that the data interpretation becomes the research outcome and therefore the substantive theory. The research methods should elaborate on the method utilized in addressing the issues including the method of analysis.

\section{Results and Discussion}

In line with the implementation of regional autonomy which gives regional governments authority to formulate policies, the role of public officials in the regions in making public policy innovations is expected to increase and to have a positive impact on the quality of policies or regulations to be drafted. Thus the quality of local regulations is an important indicator of governance performance in the regions. On the other hand, the low 
ability to innovate and willingness to innovate are challenges for public officials in government agencies both at regional and central levels.

In a pandemic situation, the responsiveness of local governments in making policy innovations is needed to respond the changes and dynamics of community demands, including in the management of MSMEs. As explained in the introduction to this article, MSMEs have many challenges in the era of the Covid-19 pandemic, one of which is the challenge related to the marketing of MSMEs products. MSMEs have obstacles in the delivery of products and services to consumers.

These challenges emerged as a result of the pandemic Covid-19 which changed people's activities, needs and search patterns. Many people choose to stay at home as recommended by the government to break the chain of Covid-19 transmission. This pandemic also made people focus on primary needs, because some of them experienced a decrease in productivity which had an impact on the income they earned. Finally, people started looking for new activities to kill boredom because activities were only carried out at home.

Responding to the dynamics of change and the demands of the people above, the Yogyakarta's Government prepared a strategic policy as a framework for economic recovery in the Yogyakarta region. The purpose of establishing this policy is to create regional social \& economic resilience in facing the Covid-19 pandemic, with three specific objectives, namely that the Covid-19 pandemic can be suppressed, the economy will rise and the creation of social resilience towards the new normal era in a sustainable manner. A number of programs and activities are prepared by the Yogyakarta's Government to support the achievement of the goals set out above. Among these programs and activities include empowering human resources through MSMEs empowerment, IT-based online marketing training and other programs and activities.

At the same time, the Yogyakarta's Government through the Office of Cooperatives and MSMEs made adjustments through a number of stages, namely improving the MSME baseline data through SIBAKUL ${ }^{9}$, the Covid impact survey on MSMEs, establishing

\footnotetext{
9 SiBakul Jogja is an acronym for the Information System for the Development of Cooperatives and Business Actors while Jogja is a popular word from the Yogyakarta Special Region Government area. SiBakul Jogja is an innovative program for the management of cooperatives and integrated MSMEs which consists of a database system and clustering / grouping for appropriate, effective, appropriate and sustainable guidance.
} 
operational procedures \& SOPs for cooperatives and MSMEs in the New Normal Era, as well as the socialization process for cooperative SOPs and MSMEs in the New Normal Era.

The adjustment process is continued with an acceleration process where the Yogyakarta's Government, through the Cooperative and MSMEs Office, collaborates with Market Hub Partners, namely Grab and Gojek, in helping MSMEs answer the challenge of delivering their products to consumers through a free shipping policy. This free shipping policy is a policy of exemption from shipping costs to consumers who shop for MSMEs products in Yogyakarta with a minimum purchase of IDR 50,000. This policy began to be implemented starting May 16, 2020. The shipping fee that is free to consumers is borne by the Yogyakarta's Government, whose funds are taken from the 2020 Yogyakarta's Regional Budget for the allocation of Covid-19 handling and regional incentive funds ${ }^{10}$. This policy also serves as a stimulus to restore people's purchasing power.

Technically, the Free Shipping policy which is the topic of this article is organized by the Cooperative and MSMEs Office for MSMEs' products that pass curation. Before using this free shipping facility, MSMEs' products must first be registered in the Sibakul application. The registration process is carried out through the application by filling out the form on the application and uploading a photo product. If it passes, there will be a notification delivered by the Cooperative and MSMEs Office Service to MSME actors through registered WhatssApp numbers. Likewise, if it doesn't pass. There will be a notification sent through No WhatsApp along with the reasons why it did not pass. MSMEs who do not pass the curation will be accompanied by the Cooperative and MSMEs Office to repair their products until they are declared eligible to be included in curation again.

As of September 2020, it was recorded that 665 MSMEs had used the free shipping facility with a total of 6,134 transactions and a total nominal delivery fee of IDR 163,355,000, . The nominal total expenditure from MSMEs is IDR 784,866,170, -. This value has driven the economy of MSMEs, consumers and online motorcycle taxis (Grab and Gojek) by 5.8 times, which is around IDR 948,221,170 million, the economy of MSMEs is rotating.

Purchases of MSMEs' products are made online or on-line with the aim of confirming the social distancing policy, through the following pages: (1) the sibakuljogja.jogjaprov.go.id

\footnotetext{
${ }^{10}$ Regional incentive funds are a reward from the Central Government to the Yogyakarta's Government for their best achievement in handling Covid-19 in the regions
} 
web as a market hub, and (2) the JOGJAKITA playstore application, which includes a SIBAKUL JOGJA menu. In short, consumers are completely free of shipping costs for products purchased from MSMEs.

MSMEs is indirectly provided with marketing media assistance with free shipping costs, because postage costs will be borne by local governments who partner with online motorcycle taxis. Orders for online motorcycle taxis are made by the Customer Service (CS) of the Yogyakarta Cooperatives \& SMSEs Office, which continues to stand-by for seven consecutive days, to help SMSEs and encourage increased public consumption.

In addition, SMSEs is also directed to adhere to health protocols in the production process to the marketing aspect, which is directed to be carried out online. Even the delivery process by motorcycle taxis is also carried out by adhering to health protocols, such as: keeping a mask, always being provided with a hand sanitizer, and giving products not being done in direct contact with consumers.

Based on this description, it is known that Sibakul Jogja Free Shipping is a policy innovation that responds to changes and dynamics of community demands related to the empowerment of MSMEs during a pandemic. By utilizing the potential of digital business resources owned by Grab and Gojek and supported by bureaucratic creativity in Yogyakarta, MSMEs' marketing problems can be resolved. The goal of policy innovation, namely to increase competitiveness and provide impact and benefits for the public interest, can also be achieved with this innovation.

\section{Conclusion}

Based on the above discussion, it can be concluded that the Yogyakarta Special Region government has generally succeeded in responding to the pandemic situation by providing various stimulus, accelerated, and sustainable programs that can be utilized and beneficial for MSMEs' actors by focusing on strengthening the empowerment of human resources for MSMEs' actors, MSMEs assistance, IT-based online marketing training and other stimulus programs and activities. In addition, the creation of various applications such as SIBAKUL and Free Ongkir and collaboration with online service providers is also a sign of the seriousness of the Yogyakarta Government's acceleration in maintaining MSMEs so that they can survive. 
The suggestion from the above discussion is that consistency in the implementation of these innovative programs is needed, especially in economic conditions that have not shown significant recovery. Consistency, which is accompanied by various monitoring and evaluation of program improvements, is expected to improve the overall quality of the program so that it has an impact on increasing the competitiveness of MSMEs actors in Yogyakarta.

\section{References}

\section{Books}

Juanda, A., \& Ulum, I. (2016). Metodelogi Penelitian Akuntansi. Klinik Skripsi Edisi, 2. Sugiyono. (2012). Memahami Penelitian Kualitatif. Bandung: AlfaBeta.

Tambunan, T. (2020). Pasar Tradisional dan Peran UMKM. PT Penerbit IPB Press.

\section{Journal article}

Adian, I., Doumbia, D., Gregory, N., Ragoussis, A., Reddy, A., \& Timmis, J. (2020). Small and Medium Enterprises in the Pandemic.

Amri, A. (2020). Dampak Covid-19 terhadap UMKM di Indonesia. BRAND Jurnal Ilmiah Manajemen Pemasaran, 2(1), 123-131.

Dev, S. M., \& Sengupta, R. (2020). Covid-19: Impact on the Indian economy. Indira Gandhi Institute of Development Research, Mumbai April.

Didier, T., Huneeus, F., Larrain, M., \& Schmukler, S. L. (2020). Financing Firms in Hibernation during the COVID-19 Pandemic.

Hadi, S. (2020). Revitalization Strategy for Small and Medium Enterprises after Corona Virus Disease Pandemic (Covid-19) in Yogyakarta. 9.

Kuckertz, A., Brändle, L., Gaudig, A., Hinderer, S., Reyes, C. A. M., Prochotta, A., ... \& Berger, E. S. (2020). Startups in times of crisis-A rapid response to the COVID-19 pandemic. Journal of Business Venturing Insights, e00169.

Pakpahan, A. K. (2020). Covid-19 Dan Implikasi Bagi Usaha Mikro, Kecil, Dan Menengah. Jurnal Ilmiah Hubungan Internasional, 59-64.

Papadopoulos, T., Baltas, K. N., \& Balta, M. E. (2020). The use of digital technologies by small and medium enterprises during COVID-19: Implications for theory and practice. International Journal of Information Management, 102192. 
Shafi, M., Liu, J., \& Ren, W. (2020). Impact of COVID-19 pandemic on micro, small, and medium-sized Enterprises operating in Pakistan. Research in Globalization, 2, 100018.

Suprihatin, W. (2020). Analisis Perilaku Konsumen Wisatawan Era Pandemi Covid-19 (Studi Kasus Pariwisata di Nusa Tenggara Barat). BESTARI, 1(1), 56-66.

Taylor, S. J., \& Bogdan, R. (1984). Introduction to qualitative research methods: The search for meanings. Wiley-Interscience.

Tyran, J.-R., \& Sausgruber, R. (2005). The Diffusion of Policy Innovations. Journal of Evolutionary Economics, 15, 423-442.

\section{Newspaper article on website}

https://www.viva.co.id/berita/bisnis/1287269-59-persen-umkm-di-diy-terdampak-

pandemi-virus-corona

\section{Website document}

https://katadata.co.id/ekarina/berita/5ed7c7e8cbb2a/survei-ilo-70-umkm-di-indonesiasetop-produksi-akibat-covid-19

Laporan Analisis Daya Saing UMKM, Bappenas, 2020 